\title{
Peningkatan Ekonomi Kreatif Digital Desa Betokan Kabupaten Demak melalui Manajemen Bisnis, Pemanfaatan Teknologi Digital, dan Sistem Informasi
}

\author{
Arizqi*, Diah Ayu Kusumawati, Ratna Novitasari \\ Prodi Manajemen, Fakultas Ekonomi, Universitas Islam Sultan Agung, Semarang, Indonesia \\ *Corresponding Author \\ Jl. Raya Kaligawe Km. 4 PO Box. 1054, Semarang 50112, Indonesia, Telp: 024-6583584, Fax: 024- \\ 6582455 \\ Email: arizqi@ unissula.ac.id
}

Received:

Revised:

9 November 20203 December 2020

Accepted:
15 December 2020

Published:

25 December 2020

\begin{abstract}
Abstrak
Desa Betokan merupakan salah satu desa yang memiliki potensi besar, mengingat desa Betokan adalah desa penghasil buah jambu dan belimbing terbesar di Kabupaten Demak. Buah jambu dan belimbing sendiri merupakan buah khas kota Demak. Meskipun demikian, sebagian besar pelaku usaha penjual jambu dan belimbing yang ada di Desa Betokan tersebut masih terkendala dalam hal manajemen usaha terutama dalam hal pemasaran dan pengembangan produk. Sehingga kegiatan pengabdian masyarakat dilakukan guna meningkatkan Ekonomi kreatif berbasis Digital masyarakat di Desa Betokan dari usaha yang telah dimiliki sehingga dapat meningkatkan pendapatan dan kesejahteraan warga desa Betokan. Metode dalam pelaksanaan pengabdian masyarakat ini antara lain penyampaian materi penyuluhan, tanya jawab dan diskusi, dilanjutkan dengan praktik. Dari pelaksanaan pengabdian masysrakat dapat disimpulkan bahwa masyarakat antusias dalam pelaksanaan penyuluhan yang dilakukan, terlebih pada saat penyampaian materi dan praktik pembuatan akun media sosial dan juga akun E-commerce seperti akun facebook, instagram, dan juga shopee. Terlebih pada masa pandemi Covid-19 seperti sekarang ini, masyarakat selaku konsumen banyak yang beralih dari pembelian secara langsung (offline) ke pembelian online. Dari adanya akun media sosial dan e-commerce ini juga pelaku usaha dapat lebih mengembangkan pasar yang ada.
\end{abstract}

Kata Kunci: Ekonomi Kreatif Digital; Manajemen Bisnis; Teknologi Digital; Sistem Informasi.

\begin{abstract}
Betokan is one of the villages that has great potential, considering that Betokan is the largest producer of guava and star fruit in Demak Regency. Guava and star fruit are the typical fruits of Demak city. Even so, most of the guava and starfruit selling business actors in Betokan are still constrained in terms of business management, especially in terms of marketing and product development. So that community service activities were carried out to improve the community-based digital creative economy in Betokan, Demak from the business that has been owned so that it can increase the income and welfare of Betokan villagers. Methods used in this community service included the delivery of extension materials, questions and answers and discussions, followed by practice. From the implementation of community service, it can be concluded that the public is enthusiastic about the implementation of the counseling carried out, especially when delivering material and practices for creating social media accounts and also e-commerce accounts such as Facebook, Instagram, and shopee accounts. Especially during the Covid-19 pandemic like now, many people as consumers have switched from direct (offline) purchases to online
\end{abstract}


purchases. From the existence of social media and e-commerce accounts, business actors can further develop existing markets.

Keywords: Digital creative economy; business management; digital technology; information systems.

\section{PENDAHULUAN}

\section{Analisis Situasi}

Desa Betokan merupakan salah satu desa yang masuk dalam wilayah Kecamatan Demak, Kabupaten Kota Demak. Desa Betokan merupakan salah satu desa yang memiliki potensi besar, mengingat desa Betokan adalah desa penghasil buah jambu dan belimbing terbesar di Kabupaten Demak. Buah jambu dan belimbing sendiri merupakan buah khas kota Demak, karena sangat banyak dihasilkan dan rasanya dinilai berbeda dengan jambu dan belimbing dari kota lainnya. Mutu yang baik dan hasil yang melimpah ruah dari buah jambu dan belimbing dihasilkan di desa Betokan. Hampir setiap warga di rumah memiliki pohon jambu atau belimbing di pekarangan rumahnya. Hal inilah yang menyebabkan melimpah ruahnya hasil dari buah jambu dan belimbing di desa Betokan. Bahkan di dusun krajan (salah satu dusun di desa betokan) hampir 97\% disetiap rumah memiliki pohon jambu atau belimbing. Selain didominasi oleh warga desa Betokan yang memiliki pohon jambu dan belimbing, ada juga petani yang memang membudidayakan perkebunan pohon jambu dan belimbing akan tetapi hanya beberapa saja. Jadi buah jambu dan belimbing yang dihasilkan di desa Betokan merupakan dari dua kategori yaitu dari hasil kebun petani jambu atau belimbing dan hasil dari pohon belimbing yang dimiliki warga dipekarangan rumahnya sendiri.

Beberapa fenomena yang biasanya terjadi dari melimpahnya hasil jambu dan belimbing di desa Betokan antara lain: 1) Biasanya hasil jambu dan belimbing tersebut akan diborong oleh tengkulak, yang biasanya dibeli dengan harga murah terlebih apabila sedang musimnya. 2) Warga akan menjualnya sendiri dengan membuka kedai kecil-kecilan didepan rumah mereka. 3) Buah jambu dan belimbing banyak yang busuk tanpa dijual atau dikonsumsi.

Adanya potensi melimpahnya hasil buah jambu dan belimbing di desa Betokan serta adanya fenomena-fenomena diatas, sehingga dalam rangka memanfaatkan hasil buah jambu dan belimbing supaya bisa bernilai jual lebih tinggi dan dapat menjadi sumber penghasilan warga, telah ada beberapa kelompok usaha yang menghasilkan produk olahan dari jambu dan belimbing, misalnya saja mereka mengolahnya menjadi dodol, manisan, asinan, dan juga sirup. Meskipun demikian, sebagian besar pelaku usaha tersebut masih terkendala dalam hal manajemen usaha terutama dalam hal pemasaran dan pengembangan produk. Kendala utamanya adalah dalam hal pemasaran produk. Selama ini produk dibuat hanya berdasarkan pesanan dan juga penjualan kecilkecilan disekitar desa sendiri. Hal tersebut dikarenakan pelaku usaha tersebut belum melakukan aktivitas promosi yang memadai, terlebih promosi melalui online seperti yang dapat dilakukan di era teknologi digital sekarang ini. 


\section{Rumusan Masalah}

Berdasarkan analisis situasi yang mana begitu besar potensi yang dimiliki oleh Desa Betokan tersebut akan tetapi masih bisa belum bisa lebih mengembangkan usaha yang ada, sehingga rumusan masalahnya adalah "Bagaimana meningkatkan Ekonomi kreatif Digital masyarakat di Desa Betokan dari usaha yang telah dimiliki sehingga dapat meningkatkan pendapatan dan kesejahteraan warga desa Betokan?"

\section{Tujuan Kegiatan}

Tujuan yang hendak dicapai dari pelaksanaan kegiatan pengabdian masyarakat ini antara lain:

1. Untuk memberikan penyuluhan dan pendampingan mengenai bagaimana memanage usaha terutama dalam hal pemasaran dan pengembangan produk sehingga dapat menjadi sumber ekonomi kreatif desa Betokan.

2. Untuk menambah pemahaman dan pengetahuan masyarakat terkait manfaat ekonomi kreatif digital dalam meningkatkan perekonomian dan kesejahteraan desa Betokan.

3. Media pembelajaran dalam mendiagnosis masalah yang dihadapi pelaku usaha olahan hasil jambu dan belimbing di desa Betokan dan membantu dalam menyelesaikan masalah yang dihadapi.

\section{Manfaat Kegiatan}

Dengan terdapatnya aktivitas pengabdian masyarakat ini diharapkan bisa memberi kepada masyarakat manfaat yang antara lain :

1. Peningkatan pengetahuan tentang bagaimana memanage usaha terutama dalam hal pemasaran dan pengembangan produk sehingga dapat menjadi sumber ekonomi kreatif di desa.

2. Masyarakat bisa menambah pemasukan serta kesejahteraan keluarga melalui pengembangan usaha ekonomi kreatif dengan memaksimalkan pemanfaatan teknologi digital dan sistem informasi termasuk didalamnya pemasaran produk.

Manajemen bisnis/usaha merupakan pengetahuan yang penting kita miliki sebelum membuka sebuah usaha. Sebab ilmu manajemen bisnis inilah yang dapat menunjang kita dalam mengatur serta melaksanakan bisnis secara benar serta pas agar dapat menggapai target - target yang sudah kita ditentukan sebelumnya (Bangun, 2012). Definisi dari manajemen ini sendiri merupakan pengelolaan yang dilakukan melalui perencanaan (planning), pengorganisasian (organizing), pengarahan (actuating), dan pengontrolan (controlling) sumber daya untuk mencapai tujuan secara efektif dan efisien. Manajemen bisnis mempunyai sekian banyak peranan yang sangat berguna untuk aktivitas bisnis, antara lain fungsi perencanaan, pengorganisasian, pengarahan, serta pengendalian.

Perlu beberapa manajemen yang harus dipersiapkan, agar bisnis dapat berjalan maksimal dan sejalan dengan rencana yang telah kita tetapkan (Peace, 2009), antara lain: 1) Manajemen keuangan, ini sangat penting karena berguna untuk mengelola keuangan bisnis agar arus kas berjalan stabil sehingga dampaknya adalah pemasukan bisnis dapat lebih besar dari pada pengeluaran. 2) Manajemen SDM, SDM merupakan hal terpenting dalam manajemen bisnis sebagai pemegang kontrol terhadap pelaksanaan 
seluruh kegiatan bisnis, termasuk didalamnya seluruh sumber daya yang lainnya yang dimiliki perusahaan seperti modal, material, market atau pasar, mesin, dan juga methode atau strategi. Karena fungsinya yang amat krusial tersebut, sehingga dibutuhkan pengelolaan khusus yang disebut juga dengan manajemen SDM. Dengan adanya manajemen yang tepat, sumber daya manusia ini diharapkan dapat saling bekerja sama dengan baik, efektif, serta efisien sehingga tujuan tercapai (Busro, 2018). 3) Manajemen operasional, dapat membantu untuk memastikan bahwa kegiatan operasional perusahaan sehari-hari berjalan sesuai rencana dan aturan yang ditetapkan. Aktivitas operasional dapat mencakup segala sesuatu yang berkaitan dengan serangkaian aktivitas produksi, mulai dari bahan baku, mesin yg digunakan, teknologi sampai strategi atau metode yang digunakan dalam mengubah bahan baku menjadi barang jadi. 4) Manajemen pemasaran, sesuatu produk ataupun jasa yang ditawarkan tidak akan dapat dikenal ataupun dilihat oleh konsumen tanpa ditawarkan ataupun diperlihatkan terlebih dulu. Disinilah peran manajemen pemasaran yang bertugas untuk memasarkan ataupun menawarkan bermacam produk serta jasa yang ditawarkan oleh sesuatu industri, agar diketahui serta membuat orang tertarik untuk membeli serta memakainya. Dalam aktivitas pemasaran harus menjadi lebih aktif melakukan promosi, terlebih apabila produk yang dihasilkan tergolong masih baru di pasaran. Pada aktivitas pemasaran ini juga, implementasi dari sebuah teknologi informasi merupakan hal yang sangat penting.

Terutama pada era globalisasi dan era revolusi industri 4.0 sekarang ini teknologi memiliki peranan yang sangat penting bagi aktivitas manusia. Oleh karena itu, implementasi dari sebuah teknologi informasi tidak dapat disepelekan, dikarenakan proses globalisasi yang berjalan begitu cepat yang memberikan pengaruh pada metode berpikir ataupun berperilaku (Achmad,et,al., 2016). Peran pentingnya teknologi informasi ini pula memberikan pengaruh pada dunia bisnis. Pada dunia bisnis, teknologi menolong banyak terlebih terkait sistem informasi yang terintegrasi dengan baik, yang mana sistem informasi yang terintegrasi dibentuk ataupun dirancang untuk menanggulangi sekaligus menunjang para pelaku bisnis dalam melaksanakan bisnis ke arah yang lebih baik. Tidak hanya itu, pekerjaan ataupun kegiatan yang berhubungan bisnis akan lebih mudah dengan menggunakan sistem kerja yang efektif dan juga efisien (Achmad, et al., 2015).

\section{METODE}

\section{Penyampaian materi penyuluhan}

Penyampaian materi penyuluhan dilakukan dengan penyampaian materi pembuka dengan penjelasan awal mengenai manajemen bisnis atau usaha yang didalamnya berisikan antara lain: penjelasan tentang dasar-dasar manajemen sebuah bisnis, apa saja yang harus di manage termasuk didalamnya terkait manajemen pemasaran. Sekaligus dalam penjelasan awal ini juga dijelaskan terkait bagaimana mengembangkan usaha. Setelah penjelasan materi awal selesai, peserta penyuluhan mendapat materi kedua mengenai bagaimana memanfaatkan teknologi digital dan sistem informasi untuk mengembangkan usaha, dengan pembahasan antara lain: pentingnya penggunaan teknologi digital dan sistem informasi di era persaingan usaha sekarang ini, bagaimana memulainya dan apa-apa saja yang bisa dilakukan dengan teknologi digital, sistem 
informasi, dan internet. Termasuk didalamnya kegiatan- kegiatan pemasaran yang bisa dilakukan dengan kecanggihan teknologi.

\section{Tanya jawab dan diskusi}

Selanjutnya, dilakukan sesi tanya jawab dan diskusi. Peserta pelatihan dapat bertanya langsung kepada pemateri atau dapat pula bertanya pada pengajar lainnya ketika menemui kendala dalam penjelasan. Kemudian dilakukan problem solving atas pertanyaan-pertanyaan yang terkait dengan masalah-masalah yang muncul.

\section{Praktik}

Setelah sesi tanya jawab dan diskusi selesai, selanjutnya adalah praktik dan membantu langsung dalam pembuatan sistem informasi yang terintegrasi seperti website (rencana website sudah kami buatkan terlebih dahulu untuk mempercepat) dan juga melatih dan pendampingan warga dalam memanfaatkan teknologi digital (handphone) untuk membantu proses pemasaran produk olahan jambu dan belimbing mereka dengan membuat akun-akun media sosial seperti instagram, facebook, dan juga membuatkan akun penjualan e-commerce yang sekarang sedang marak yaitu shopee, lazada, atau yang lainnya.

\section{HASIL DAN PEMBAHASAN}

Kegiatan pengabdian masyarakat ini merupakan bagian dari pelaksanaan Tri dharma Perguruan Tinggi yang dilaksanakan pada tanggal 17 Oktober 2020 mulai jam 09.00 WIB hingga selesai kurang lebih pukul 14.30. Perlu disampaikan bahwa pada rencana awal, pelaksanaan pengabdian masyarakat ini akan dilaksanakan pada bulan Agustus 2020 dengan perkiraan dan harapan pada bulan agustus tersebut kondisi yang diakibatkan oleh wabah Covid-19 sudah kembali normal. Pada kenyataannya hingga saat ini pun kondisi masih mengharuskan untuk menjaga jarak, dilarang berkumpul banyak orang, dan yang lainnya. Dengan kondisi tersebut sehingga tanggal pelaksanaan pengabdian masyarakat ini tidak sesuai dengan jadwal semula. Pelaksanaan pengabdian ini dilakukan pada tanggal 17 Oktober 2020 di Desa Betokan Rt. 001, Rw. 007 Kec. Demak dan tepatnya di rumah Ibu Samirah selaku ketua kelompok usaha.

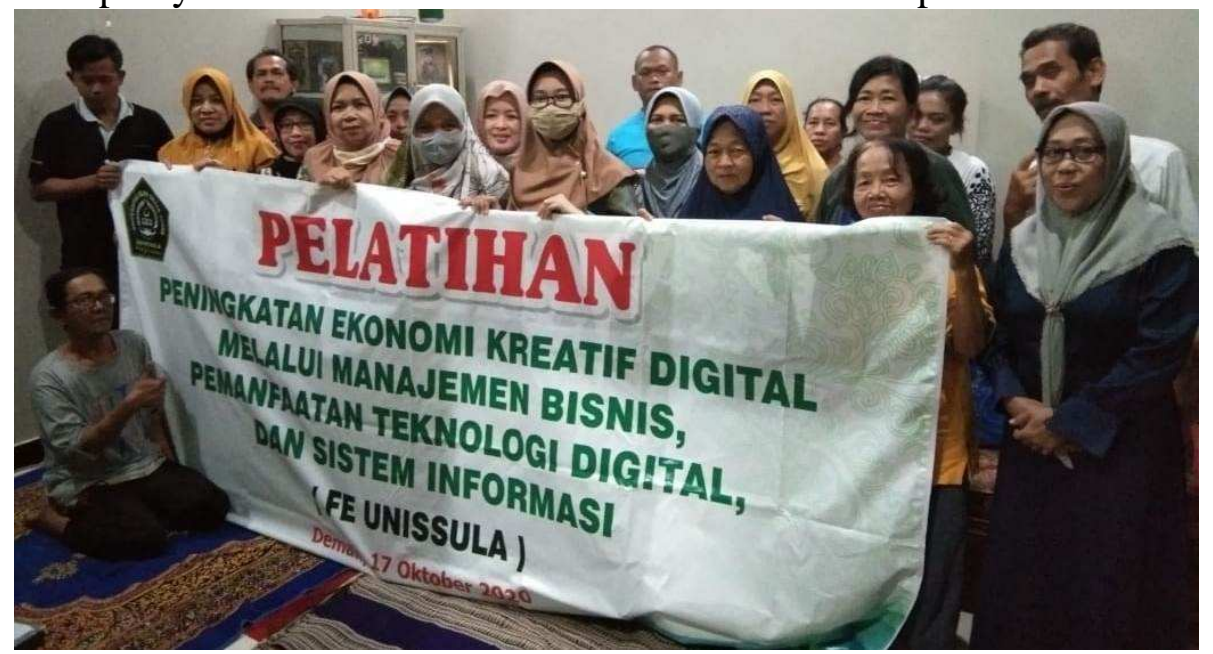

Gambar 1. Foto bersama dengan peserta setelah pelaksanaan pelatihan 


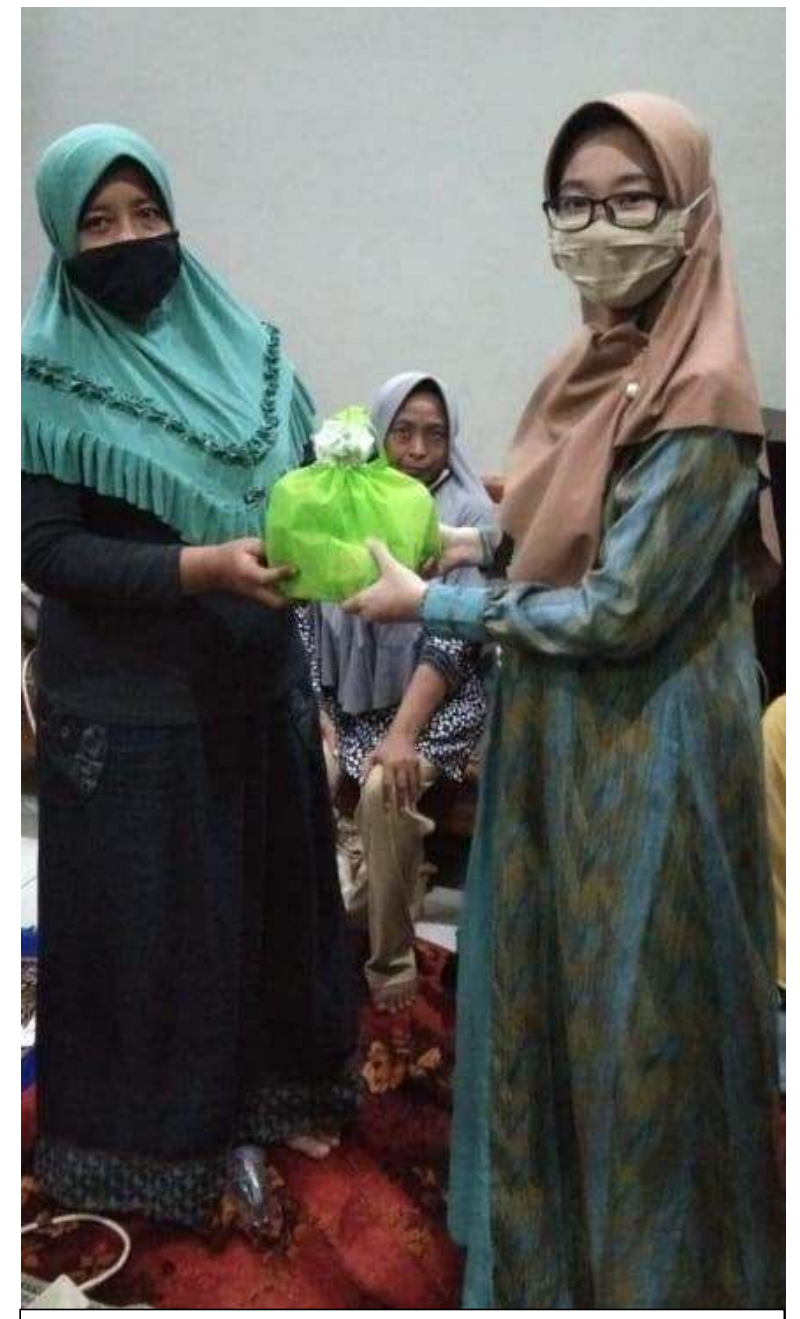

Gambar 2. Penyerahan cendera mata ke peserta
Pelaksanaan kegiatan pengabdian ini diawali dengan penyampaian materi pembuka dengan penjelasan awal mengenai manajemen bisnis atau usaha. Setelah penjelasan materi awal selesai, peserta penyuluhan mendapat materi kedua terkait bagaimana memanfaatkan teknologi digital dan sistem informasi untuk mengembangkan usaha. Selanjutnya, dilakukan sesi tanya jawab dan diskusi. Peserta pelatihan dapat bertanya langsung kepada pemateri atau dapat pula bertanya pada pemateri lainnya ketika menemui kendala dalam penjelasan. Kemudian dilakukan problem solving atas pertanyaan yang disampaikan terkait dengan masalah yang dihadapi. Selanjutnya untuk sesi praktik secara langsung dan pendampingan diawali dengan penjelasan dan kemudian praktik pembuatan akun media sosial dan juga akun E-commerce seperti facebook dan juga shopee. Sebelum acara dimulai penyelenggara telah memberikan voucher kuota internet kepada semua peserta pelatihan. Pada praktik bersama ini penyuluh membuat contoh akun bersama untuk penjual jambu dan belimbing di desa Betokan yang selanjutnya dapat membuat akun-akun pribadinya sendiri jika menghendaki. Salah satu akun bersama yang sudah dibuat adalah akun facebook dengan nama akun "Jambu Belimbing Demak". Dimana akun ini akan mempromosikan hasil jambu dan juga belimbing serta produk yang dihasilkan dari desa Betokan.

Keberhasilan kegiatan pengabdian masyarakat ini ditunjukkan dari antusias peserta mendengarkan penyuluhan dari materi-materi yang disampaikan dan terlebih dari praktik langsung terkait pembuatan akun media sosial dan e-commerce. Terlebih pada masa pandemi Covid-19 seperti sekarang ini, masyarakat selaku konsumen banyak yang beralih dari pembelian secara langsung (offline) ke pembelian online. Dari adanya akun media sosial dan e-commerce ini juga pelaku usaha dapat lebih mengembangkan pasar yang ada.

140 || Indonesian Journal of Community Services 


\section{KESIMPULAN}

Berdasarkan rumusan masalah dan kegiatan pengabdian masyarakat yang telah dilakukan, maka kesimpulan dari kegiatan masyarakat ini antara lain: 1) Masyarakat antusias dalam pelaksanaan penyuluhan yang dilakukan, terlebih pada saat penyampaian materi dan praktik pembuatan akun media sosial dan juga akun E-commerce. 2) Berdasarkan rumusan yang ada, sehingga untuk meningkatkan Ekonomi kreatif Digital masyarakat di Desa Betokan dari usaha yang telah dimiliki, maka dapat ditingkatkan melalui Manajemen Bisnis yang baik, Pemanfaatan Teknologi Digital, dan Sistem Informasi.

\section{UCAPAN TERIMA KASIH}

Tiada kata yang layak kami sampaikan kepada semua pihak yang telah memberikan bantuan, dorongan, saran dan sumbangan pemikiran dalam pelaksanaan kegiatan pengabdian masyarakat ini, kecuali ungkapan rasa terima kasih yang setinggi-tingginya. Melalui kesempatan ini kami menyampaikan ucapan terima kasih kepada Bapak Drs. Bedjo Santoso, MT, PhD selaku Rektor Universitas Islam Sultan Agung Semarang, LPPM Unissula yang telah menyelenggarakan dan memfasilitasi kegiatan pengabdian masyarakat di lingkungan Unissula, Prof. Olivia Fachrunnisa, SE, M.Si, Ph.D, selaku Dekan Fakultas Ekonomi Universitas Islam Sultan Agung, Ibu Samirah selaku ketua kelompok usaha di Desa Betokan Kab. Demak, dan Bapak Naryanto selaku Ketua RT. 01, RW. 07, Desa Betokan Kab. Demak yang telah memberikan ijin untuk melaksanakan kegiatan pengabdian masyarakat ini serta Bapak dan Ibu peserta pengabdian masyarakat.

\section{DAFTAR PUSTAKA}

Achmad, N., \& Saputro, E.P. (2015). Isu riset kewirausahaan. Jakarta: Direktorat Penelitian Pengabdian Masyarakat Dirjen Dikti.

Achmad, N., Saputro, E. P., \& Handayani, S. (2016). Kewirausahaan di era digital. Jakarta: Direktorat Penelitian Pengabdian Masyarakat Dirjen Dikti.

Bangun, W. (2012). Manajemen sumber daya manusia. Jakarta: Erlangga.

Busro, M. (2018). Teori-teori manajemen sumber daya manusia. Jakarta: Prenadamedia Group.

Endyana, C. (2019). Peningkatan kualitas lingkungan hidup dengan pengembangan ekonomi kreatif warga Desa Cileunyi Wetan Kabupaten Bandung. Kumawula. Jurnal Pengabdian Masyarakat. Volume 2, Nomor 3, Desember 2019: 201-210.

Hermayunita. (2011). Peran penyuluh pertanian lapangan (PPL) dalam penerapan pertanian organik di Kenagarian Koto Tinggi Kecamatan Baso Kabupaten Agam. Skripsi. Padang: Universitas Andalas.

LPPM Unissula. (2020). Buku panduan pengabdian kepada masyarakat internal Unissula. Semarang: LPPM Universitas Islam Sultan Agung.

Maslim, A., \& Nugroho. (2020). Pembangunan sistem informasi penjualan pada usaha mikro, 
Indonesian Journal of Community Services

Volume 2, No. 2, November 2020

http://jurnal.unissula.ac.id/index.php/ijocs

DOI: http://dx.doi.org/10.30659/ijocs.2.2.135-142

kecil dan menengan. Dinamisia: Jurnal Pengabdian Kepada Masyarakat. Volume 4, Nomor 1, Maret 2020: 95-105.

Peace II, (2009). Management. New York: McGraw-Hill Book.

Sunanik. (2013). Penguatan ekonomi kreatif dan inovatif berbasis sumber daya Desa Besuki di Kecamatan Besuki Tulungagung. J-Adimas. Volume 1, Nomor 1, Juli 2013: 20-27. 